\title{
Correction to: Is prehospital use of active external warming dangerous for patients with accidental hypothermia: a systematic review
}

Sigurd Mydske $e^{1,2^{*}}$ and Øyvind Thomassen ${ }^{1,2,3}$

\section{Correction to: Scand J Trauma Resusc Emerg Med https://doi.org/10.1186/s13049-020-00773-2}

Following the publication of the original article [1], the authors became aware of two issues they would like to communicate to the readers:

1) In Fig. 1, second column, the number in the 'Studies included' box shows 9 instead of 8 . The correct figure is included in this Correction.

2) In the 'Study selection' section, the symbol for the Kappa Coefficient shows up blank instead of $(\kappa)$.

\section{Author details}

'Department of Anaesthesia and Intensive Care, Haukeland University Hospital, Bergen, Norway. ${ }^{2}$ Mountain Medicine Research Group, University of Bergen, Bergen, Norway. ${ }^{3}$ Department of Research and Development, Norwegian Air Ambulance Foundation, Oslo, Norway.

Published online: 26 October 2020

\section{Reference}

1. Mydske, Thomassen. Is prehospital use of active external warming

dangerous for patients with accidental hypothermia: a systematic review.

Scand J Trauma Resusc Emerg Med. 2020;28:77 https://doi.org/10.1186/ s13049-020-00773-2.

\footnotetext{
The original article can be found online at https://doi.org/10.1186/s13049020-00773-2.

*Correspondence: sigurd.mydske@gmail.com

'Department of Anaesthesia and Intensive Care, Haukeland University Hospital, Bergen, Norway

${ }^{2}$ Mountain Medicine Research Group, University of Bergen, Bergen, Norway

Full list of author information is available at the end of the article
}

(c) The Author(s). 2020 Open Access This article is licensed under a Creative Commons Attribution 4.0 International License, which permits use, sharing, adaptation, distribution and reproduction in any medium or format, as long as you give appropriate credit to the original author(s) and the source, provide a link to the Creative Commons licence, and indicate if changes were made. The images or other third party material in this article are included in the article's Creative Commons licence, unless indicated otherwise in a credit line to the material. If material is not included in the article's Creative Commons licence and your intended use is not permitted by statutory regulation or exceeds the permitted use, you will need to obtain permission directly from the copyright holder. To view a copy of this licence, visit http://creativecommons.org/licenses/by/4.0/ The Creative Commons Public Domain Dedication waiver (http://creativecommons.org/publicdomain/zero/1.0/) applies to the data made available in this article, unless otherwise stated in a credit line to the data. 


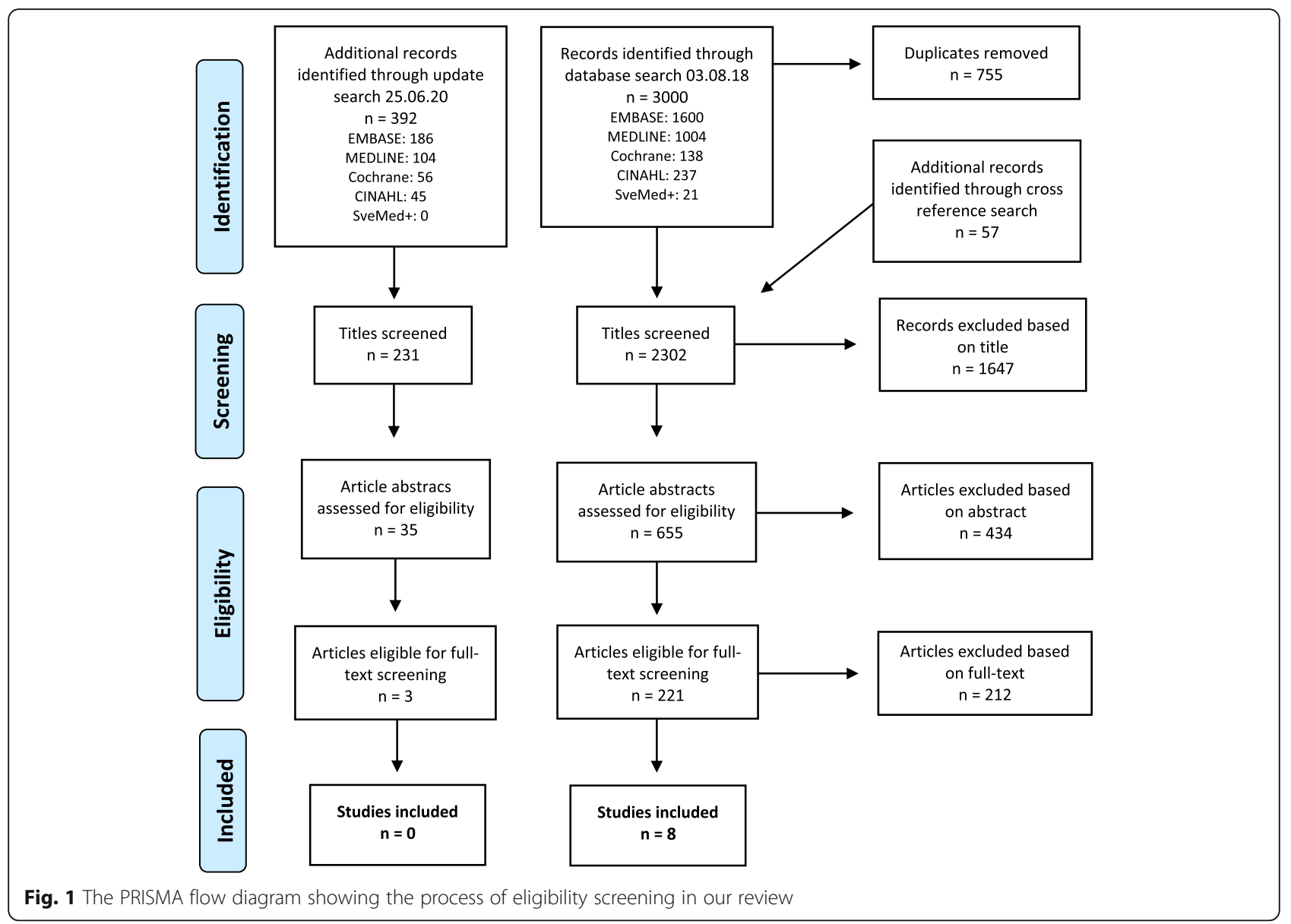

